\title{
Design of longitudinal finned tubes adjusted with the Cesòro curve
}

\author{
Diseño de tubos con aletas longitudinales ajustados con la curva de \\ Cesòro
}

Desenho de tubos com aletas longitudinais ajustados com a curva de Cesòro

Fecha de recepción: 8 de diciembre de 2017

Luis Eduardo Llano-Sánchez

Luis Carlos Ruiz**

Fecha de aprobación: 5 de marzo de 2018

Darío Manuel Domínguez-Cajeli"**

Martha Cecilia Melo-de-Alonso

\section{Abstract}

This paper proposes a process of higher heat transfer efficiency, through a fractal design over Cesàro curve as an extend surface for an exchange tube. Our designs yielded better results applying finite element analysis compared with the smooth surface commonly used in the industry. This new adaptation can be oriented toward applications involving gases and viscous liquids, for devices such as motors, boilers and dissipaters, among others.

Keywords: Cesàro curve; fractal geometry; heat exchangers; heat transfer; longitudinal extended surfaces.

\section{Resumen}

Este artículo propone un proceso de transferencia de calor altamente eficiente a través del diseño fractal a partir de la curva de Cesàro de tubos de intercambio con superficie extendida. Aplicando análisis de elementos finitos, nuestros diseños arrojaron mejores resultados comparados con los tubos de superficie lisa, comúnmente utilizados en la industria. Esta nueva adaptación puede ser orientada a aplicaciones que involucren gases y líquidos viscosos, en máquinas como motores, calderas y disipadores, entre otros.

Palabras clave: Curva de Cesàro; geometría fractal; intercambiadores de calor; superficies longitudinales extendidas; transferencia de calor.

\footnotetext{
* Universidad Militar Nueva Granada (Bogotá - Distrito Capital, Colombia). luis.llano@unimilitar.edu.co. ORCID: 0000-0001-7372-0437.

** Universidad Militar Nueva Granada (Bogotá - Distrito Capital, Colombia). u3900195@unimilitar.edu.co.

*** Universidad Militar Nueva Granada (Bogotá - Distrito Capital, Colombia). dario.dominguez@unimilitar.edu.co.

****Universidad Militar Nueva Granada (Bogotá - Distrito Capital, Colombia). martha.melo@unimilitar.edu.co.
} 


\section{Resumo}

Este artigo propõe um processo de transferência de calor altamente eficiente através do desenho fractal a partir da curva de Cesàro de tubos de intercâmbio com superfície estendida. Aplicando análise de elementos finitos, nossos desenhos produziram melhores resultados comparados com os tubos de superfície lisa, comumente utilizados na indústria. Esta nova adaptação pode ser orientada a aplicações que envolvem gases e líquidos viscosos, em máquinas como motores, caldeiras e dissipadores, entre outros.

Palavras chave: Curva de Cesàro; geometria fractal; permutadores de calor; superfícies longitudinais estendidas; transferência de calor.

\section{Para citar este artículo:}

L. E. Llano-Sánchez, L. C. Ruiz, D. M. Domínguez-Cajeli, and M. C. Melo-de-Alonso, "Design of longitudinal finned tubes adjusted with the Cesàro curve," Revista Facultad de Ingeniería, vol. 27 (48), pp. 71-78, May. 2018. 


\section{INTRODUCTION}

\section{A. Fractal geometry and its applications}

Fractal geometries are those geometric relationships that are responsible for interpreting and representing the various forms of nature [2]; in addition, they allow measuring the irregularity of the objects, the natural processes and the physiology of the human body [3]. Among the most representative fractal geometries are the Koch snowflake, the rug of Sierpinski and the Cesàro curve [4]. Similarly, the structure of irregular objects (e.g., the organs of the human body) [5], the micro-organisms, the growth of normal and carcinogenic cells [6], and the cerebral blood flow in people with Alzheimer's have been analyzed. Previous research has been able to develop tissues from biocompatible materials from fractal biomimeticas geometries, which seek to obtain tissues similar to those of the living organisms [7].

In geology, calculations aimed at determining the level of a geological fault in an area have been done from the fractal dimension [2, 8]; likewise, geo-forms such as planets or drainage basins have been analyzed [9]. In engineering, nano-level antennas have been developed with fractal geometries $[10,11]$. The fractal exponent of Hurst has been proposed as an application in mechanical engineering; it allows analyzing signals in the process of machining to avoid system failures $[12,13]$ and visualizing the behavior of the scaling of fracture surfaces in composite materials, using fractal fractures [14]. In mathematics, software has been developed as a winch with fractal foundation, to identify numerical patterns and improve the transition from arithmetic to algebra [15].

\section{B. Heat exchangers and heat transfer}

The industry has developed mechanisms that improve heat transfer, like designing stoves with a combination of materials that reduce heat loss [16]. Other variable considered is the convective coefficient, which facilitates the exchange of temperature during heating, cooling or freezing [17]. An example of such mechanisms is the one developed for minimizing the entropy in the heat transfer of electrical circuits, which raises the need to design cooling devices to avoid possible damages to the elements that make up the circuit [18]. Therefore, it is necessary to continue studying heat transfer in elements such as tubes, from their length to the number of Reynolds, for adjusting the pipe bench [19]. In this sense, software that exposes the dynamics and control of heat exchangers of tubes and armor, of interactive use between the student and the same one, have been developed [20].

Implementing combustion gases to heat air is one of the commonly used methods [21]; in other cases, various pipe configurations have been developed to improve the storage of fluids at high temperatures. A main element in the heat transfer process is the extended surface tube, which generated great interest in the field of mathematical modeling to improve the efficiency of heat generation [22]. In this case, the type of fin determines the characteristics of the flow and the resulting transfer coefficient, whose studies have focused on numerical analyses from commercial software [23].

In this study, we first explain the methodology used to design and analyze the extended surface of the Cesàro curve for tubes arranged for heat exchangers. In this case, the piece was developed with the computer-aided design (CAD) SolidWorks, to conduct the analysis with the finite elements computer-aided engineering (CAE) ANSYS. Second, we compare the commercial longitudinal extended surface tube with the results obtained, showing that the flow in the heat transfer process is better.

\section{Methodology}

The design of the tube with extended fractal tree surface began by elaborating a sketch (Fig. 1). To perform the geometry that corresponds to the Cesàro curve, a hexagon was made, assigning its function as base geometry, then the procedure was implemented to obtain a fractal tree, where the idea was to draw the base of the tree and in each iteration replicate the tree with its branches on its corresponding scales [24]. 

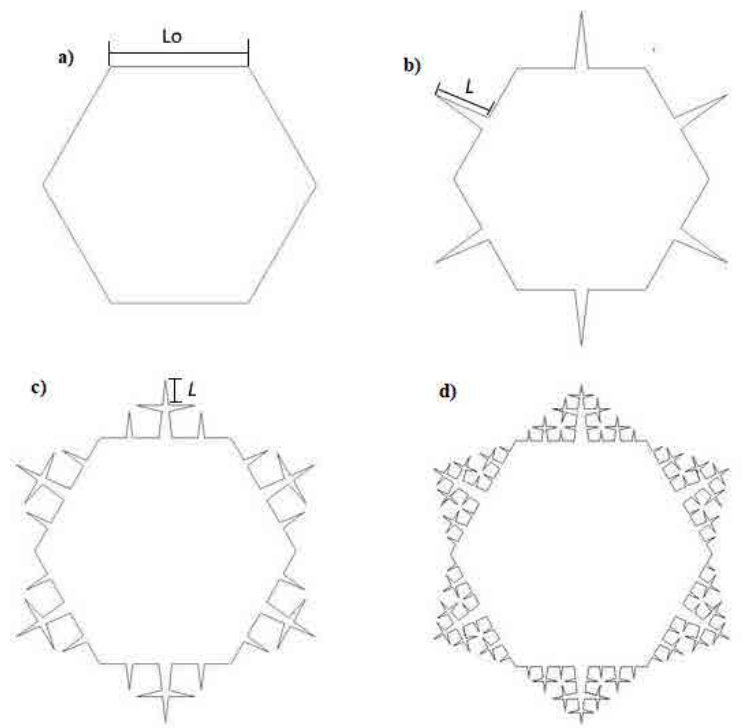

Fig. 1. Design and elaboration of fractal tree to implement on extended surfaces, where a) is the base geometry, b) is associated to each side of the base of the tree, c) is placed at the base and the branches and d) is a replica of the base of tree the branches on a smaller scale.

To understand better how to obtain each fin of the tube with the Cesaro curve, we considered equation (1), which indicates the length corresponding to each branch from the initial length of the fin (L) and the iteration to be replicated.

$$
L=L_{\circ} *\left(\frac{1}{2}\right)^{n}
$$

After making the sketch to implement the fractal tree on the extended surface of a tube for heat exchangers, we designed the tube with the computer-aided design (CAD) SolidWorks (Fig. 2). The initial design of the tube with extended surface allowed performing the analysis by finite elements with the computer-aided engineering (CAE) ANSYS, to evaluate the rate of heat transfer and its behavior.

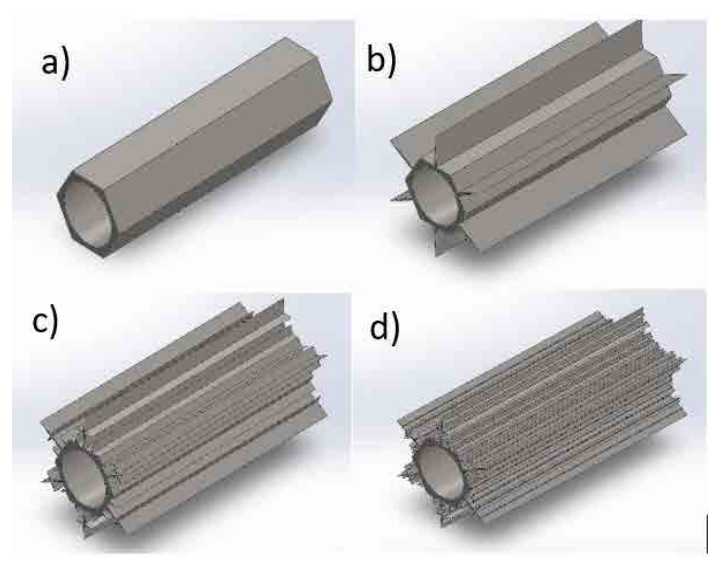

Fig. 2. CAD design of the tubes for the analysis by finite elements of the heat transfer, where each of the figures correspond to the solid developed from the proposed sketches.

The analysis was carried out by finite elements, where it was necessary to enter and adjust the internal surface at a temperature of $200{ }^{\circ} \mathrm{C}$, assigning to the copper tube a coefficient of thermal conductivity of $400 \mathrm{~W} /(\mathrm{M}$ $\left.*{ }^{\circ} \mathrm{C}\right)$, then a room temperature $\left(22^{\circ} \mathrm{C}\right)$ was assigned with a thermal convection coefficient of $5 \mathrm{~W} /\left(\mathrm{M}^{2 *}\right.$ $\left.{ }^{\circ} \mathrm{C}\right)$. The development of CAE analysis tools, from logistical models, can be estimated with the so-called fractional or fractional model [25], of the type MittagLeffler generalized, developed from the equation (2), where $\alpha, \beta>0 \alpha, \beta>0$.

$$
E_{\alpha, \beta}(x)=\sum_{n=0}^{\infty} \frac{x^{n}}{\Gamma(\alpha n+\beta)}
$$

When $\alpha=\beta=1$, you get a function $\operatorname{Exp}(\mathrm{x})=\mathrm{e}^{\wedge} \mathrm{x}$, which leads to the conclusion that the generalized function of Mittag-Leffler resembles the widespread exponential function; therefore, it was possible to estimate the generalized logistic models [26]. To conduct a mathematical approximation, the model of the smooth tube was adjusted with equation (3), starting from the conditions suggested in [27].

$$
\varphi(t)=\frac{K}{1+b \operatorname{Exp}(-a t)}
$$




\section{RESULTS}

After designing the tubes to be evaluated, we analyzed the Steady State Thermal in ANSYS, which allows evaluating the temperature variation and heat flow by convection, conduction and radiation between different media, like solids and fluids. For this case, we obtained the thermal flow or heat transfer that is shown in Fig. 3.

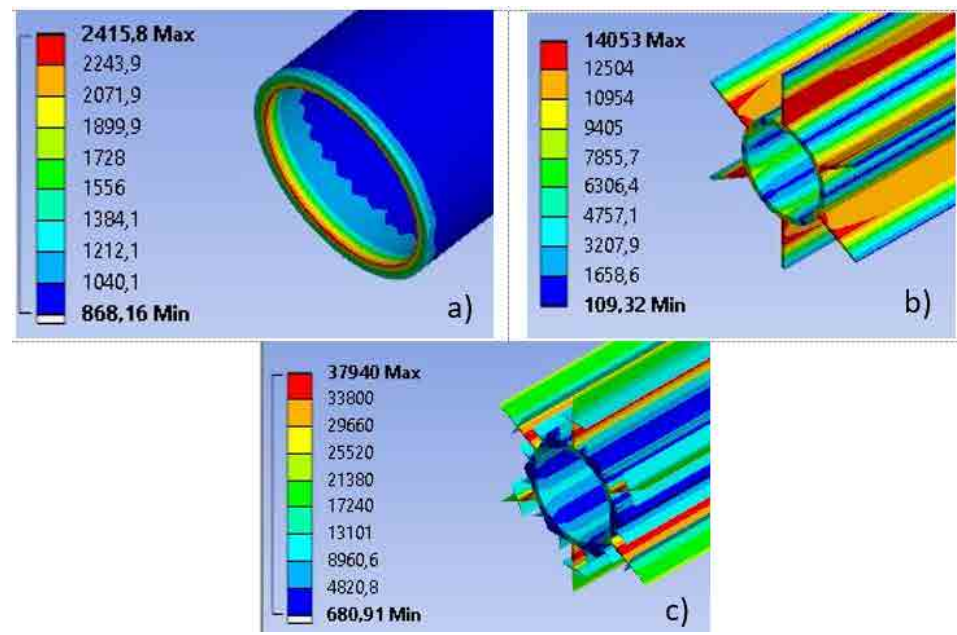

Fig. 3. Thermal flow between a fluid with a temperature of $200{ }^{\circ} \mathrm{C}$ in the interior of the tube and $22{ }^{\circ} \mathrm{C}$ on the outside, posing the analysis for a) smooth tube, b) extended surface tube of longitudinal fins, c) tube with extended surface of longitudinal fractal tree.

Fig. 4 shows that the finned tube extended with fractal tree geometry presents a better behavior, suggesting that a greater heat flux may be possible. For the comparison shown in Fig. 4, we took three equally spaced values of the simulation: $\varphi_{1}=140.5 ; \varphi_{2}=538.47 ; \varphi_{3}=2655.3$ $\varphi_{1}=140.5 ; \varphi_{2}=538.47 ; \varphi_{3}=2655.3$, which were replaced in equation (4) to get $\omega=-5,5 \omega=-5,5$.

$$
\frac{\frac{1}{\varphi_{3}}-\frac{1}{\varphi_{2}}}{\frac{1}{\varphi_{2}}-\frac{1}{\varphi_{2}}}=\operatorname{Exp}(-0.3 \omega)
$$

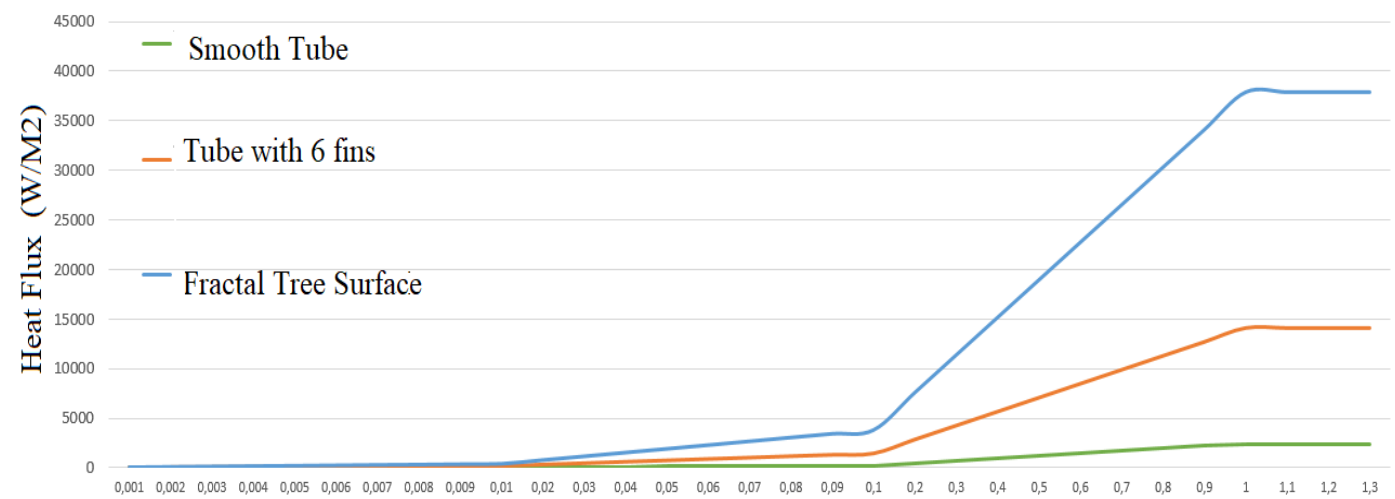

Time (s)

Fig. 4. Heat flow comparison between the smooth tube (green line), the tube with an area of longitudinal fins (orange line), and the tube with an extended surface with fractal tree (blue line).

Subsequently, to obtain the parameters for the other extended surfaces, we considered the data shown in Table 1. 


\section{TABLE 1}

LOGISTIC MODEL FOR OTALL TUBE'S CONFIGURATIONS

\begin{tabular}{|c|c|c|c|}
\hline Tube settings & Alpha value $(\alpha)$ & Beta value $(\beta)$ & Estimated equation \\
\hline Smooth Tube & 1 & 1 & $\varphi(t)=\frac{40500}{1+600 E_{1,1}(-5.5 t)}$ \\
\hline longitudinal fins & 0,4 & 1 & $\varphi(t)=\frac{40500}{1+600 E_{0.4,1}(-5.5 t)}$ \\
\hline Cesaro curve & 0,4 & 2,5 & $\varphi(t)=\frac{40500}{1+600 E_{0.4,2.5}(-5.5 t)}$ \\
\hline
\end{tabular}

The results of graphing $t \in[0,1.4] t \in[0,1.4]$ are shown in Fig. 5 .

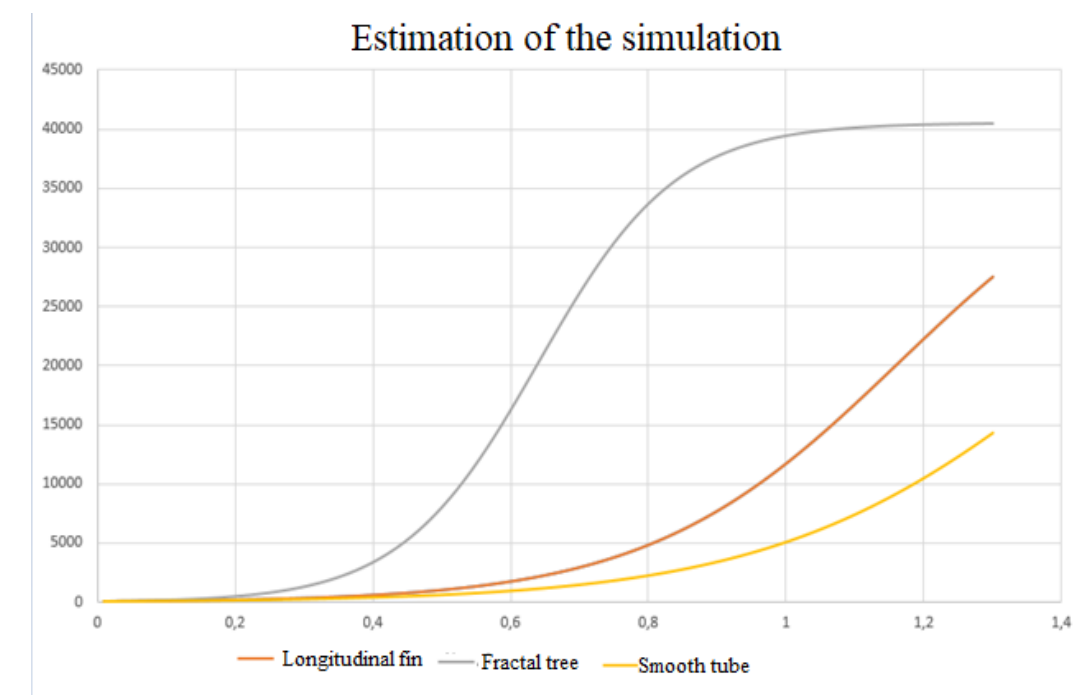

Fig. 5. Simulations using the general logistic model of Mittag-Leffler for each tube

\section{Discussion}

The results obtained lead us to conclude that implementing fractal tree as an extended surface in tubes arranged for heat exchangers allows a greater transfer of heat between the fluid in the inside and the outside of the tube. The evaluated extended surface increases the contact surface and expands the edges of the extended surface, which facilitates the heat exchange, because it improves the turbulence of the fluid and thus the transfer of heat.

\section{Conclusions}

Implementing fractal geometries of mechanic areas has generated great interest for developing materials, and improving their internal structure to enhance mechanical properties such as maximum effort and durability. In this case, by implementing the fractal tree at the macro level, as an extended surface, it is possible to improve heat transfer, which can favor thermal processes in heat exchangers in capacitors and refrigerants, among others.

As a future work we are working on assigning application designs to industrial and domestic devices, which will allow demonstrating real-time behavior to meet the three main design lines: CAD, finite element analysis and item production. This process is proposed with the aim of reaching the market and increasing the handling capacity of high and low temperatures depending on their application

\section{ACKNOWLedgment}

The authors thank the vice-rector of research of the Universidad Militar Nueva Granada who funded 
the research project ING INV 2117 titled "Design of fractal structures for engineering" since 2016; likewise, the authors thank engineer C. González

\section{REFERENCES}

[1] L. E. Llano-Sánchez, D. M. Domínguez-Cajeli, and L. C. Ruiz-Cárdenas, "Thermal transfer analysis of tubes with extended surface with fractal design," Rev. Fac. Ing., vol. 27 (47), pp. 31-37, Jan. 2018. DOI: $\quad$ https://doi.org/10.19053/01211129.v27. n47.2018.7749.

[2] O. Y. Quintero Delgado, and J. Ruiz Delgado, "Estimación del exponente de Hurst y la dimensión fractal de una superficie topográfica a través de la extracción de perfiles," Revista Geomática, vol. 5, pp. 84-91, Jul. 2011.

[3] A. Domínguez Monterroza, and D. Garzón Alvarado, "Comportamiento fractal espacial en la expansión de la distribución del flujo sanguíneo cerebral en Alzheimer," Revista Cubana de Investigaciones Biomédicas, vol. 30 (3), pp. 424-438, 2011.

[4] F. Vallejo López, "La geometría fractal: los fractales, sus aplicaciones, y didáctica," Reflexiones y experiencias innovadoras en el aula, vol. 20, pp. 1-10, May. 2010.

[5] J. Rodríguez, S. Prieto, C. Correa, P. Bernal, L. Álvarez, G. Forero, S. Vitery, G. Puerta, and I. Rojas, "Diagnóstico fractal del ventriculograma cardiaco izquierdo. Fractal Geometry of ventriculogram during cardiac dynamics," Revista Colombiana de Cardiología, vol. 19 (1), pp. 18-24, Jan. 2012. DOI: https://doi.org/10.1016/S0120-5633(12)70099-2.

[6] J. Rodríguez, S. Prieto, C. Correa, H. Posso, P. Bernal, G. Puerta, S. Vitery, and I. Rojas, "Generalización fractal de células preneoplásicas y cancerígenas del epitelio escamoso cervical. Una nueva metodología de aplicación Clínica," Revista Med, vol. 18 (2), pp. 173 - 181, Nov. 2010. DOI: https://doi.org/10.18359/ rmed.1310.

[7] A. Díaz Lantada, P. Lafont Morgado, P. Ortego García, J. M. Muñoz-Guijosa, J. L. Muñoz Sanz, J. Echavarri Otero, E. Chacón Tanarro, and E. de la Guerra Ochoa, "Diseño y fabricación rápida de geometrías biomiméticas fractales en materiales biocompatibles para aplicaciones en ingeniería de tejidos," in Congreso Nacional de Ingeniería Mecánica, Castellon, 2010.

[8] K. J. Toro Salas, L. F. Murcia Durán, and D. Domínguez Cajeli, "Cálculo de la dimensión fractal de la falla geológica del suroccidente de Colombia," Ciencia e ingeniería neogranadina, vol. 17 (1), pp. 35-45, Jun. 2007.

[9] G. N. Moscatelli, and J. J. Ibáñez, “Autoorganización espacio-temporal y procesos de escalamiento en Geomorfología y sus aplicaciones,” 2010 [online].
Available: https://www.researchgate.net/profile/ Juan_Ibanez3/publication/255981975_Autoorganizacin_espaciotemporal_y_procesos de_escalamiento_en_geomorfologa_y_sus aplicaciones._Un_ensayo_de_edafologa_virtual/ links/00b7d52-13ae-0e470c80000000.pdf.

[10] G. Vera Reveles, "Geometrías fractales en antenas y dispositivos optoelectrónicos," 2006.

[11] R. D. E. H. Castro Rivera, and V. H. Galvis Botía, "Antenas Nano-Estructuradas: de su construcción como fractales," Bogotá, 2014.

[12] D. Pérez Canales, J. C. Jauregui Correa, and L. Vela Martínez, "Detección de inestabilidades dinámicas en procesos de rectificado mediante la transformada continua de ondeletas y el exponente fractal de Hurst," Ingeniería Mecánica, Tecnología y Desarrollo, vol. 4 (3), pp. 89-98, Jul. 2012.

[13] O. Hilders, "Mecánica de fractura fractal: efectos a micro y nanoescala. Parte I: Tenacidad y mecanismos de fractura a microescala," Revista de la Facultad de Ingeniería U.C.V., vol. 26, pp. 55-80, Jun. 2011.

[14] C. A. Mora Santos, "Comportamiento del escalamiento de superficies de fractura en materiales compuestos," 2012 [online]. Available: http://tesis. bnct.ipn.mx/handle/123456789/10173.

[15] J. F. Puerto Monterroza, "El uso de fractales para potenciar el desarrollo del pensamiento algebraicovariacional a través del software cabri -del pensamiento numérico al pensamiento algebraico variacional-," Educación Científica y Tecnológica, pp. 737-741, Ago. 2013.

[16] J. D. Aristizábal Hernández, "Estufas mejoradas y bancos de leña: una alternativa de autoabastecimiento energético a nivel de finca para comunidades dependientes de los bosques de roble de la cordillera Oriental," Colombia Forestal, vol. 13 (2), pp. 245265, Dec. 2010. DOI: https://doi.org/10.14483/ udistrital.jour.colomb.for.2010.2.a05.

[17] A. Alvis, I. Caicedo, and P. Peña, "Determinación del Coeficiente de Transferencia de Calor a través de una aplicación de computadoras," Información Tecnológica, vol. 21 (5), pp. 13-20, 2010. DOI: https://doi.org/10.4067/S0718-07642010000500003.

[18] R. Correa Cely, I. Amaya Contreras, and A. Araque Herrera, "Uso de algoritmos metaheurísticos híbridos para la minimización de entropía en problemas de transferencia de calor en circuitos electrónicos," Ingeniería y Universidad, vol. 15 (2), pp. 403-421, 2011.

[19] Y. Pysmennyy, G. Polupan, I. Carvajal-Mariscal, and F. Sánchez Silva, "Estudio comparativo de los métodos del cálculo de la transferencia de calor en banco de tubos," Cientifica, vol. 14 (1), pp. 17- 23, 2010 .

[20] O.U.Fiderman Machuca, "Software para la enseñanza de la dinámica y control de intercambiadores de calor 
de tubos y coraza," Revista Facultad de Ingeniería, vol. 44, pp. 52-60, 2008.

[21] C. F. López Ruano, and L. A. Trejo Flores, "Diseño y construcción de un intercambiador de calor directo para horno cubilote," Master Thesis, Escuela Politécnica Nacional, Quito, 2013.

[22] F. A. Saavedra Balderas, F. J. Ortega Herrera, J. Torres Jiménez, M. d. R. González Ponce, A. Lozano Luna, and R. A. Rodríguez Moreno, "Efecto de la sección transversal en la eficiencia de los disipadores de calor formados por aletas," in XII Encuentro Participación de la Mujer en la Ciencia, Guanajuato, 2015.

[23] Y.A. Loredo Sáenz, "Caracterización termohidráulica del área de transferencia de calor en superficies extendidas mediante simulación numérica," Master Thesis, Universidad Autónoma de Nuevo León, Nuevo León, 2014.

[24] A. Arbiser, "Para mirar con lupa: los fractales," Acheronta, vol 2, pp. 113-128, Dec. 1995.

[25] H. J. Haubold, A. M. Mathai, and R. K. Saxena, "Mittag-Leffler Functions and their applications," Journal of Applied Mathematics, vol. 2011, pp. 1-52, 2011. DOI: https://doi.org/10.1155/2011/298628.

[26] S. Rogosin, "The Role of the Mittag-Leffler Function in Fractional Modeling," Mathematics, vol. 3 (2), pp. 368-381, 2015. DOI: https://doi.org/10.3390/ math3020368.

[27] G. J. S. Ross, Nonlinear Estimation, Springer Series in Statistics, New York: Springer, 1990. 